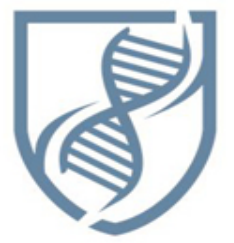

Journal of Bioscience and Applied Research

\section{JBAAR}

WWW.JBAAR.ORG

\title{
Ultrastructural study on the foot and the shell of the oyster Pinctada radiata (leach, 1814),(Bivalvia: Petridae)
}

\author{
Eman H. Radwan ${ }^{1}$, Gaber A. Saad ${ }^{2,4}$, Sherifa Sh. Hamed ${ }^{3,4}$
}

\begin{abstract}
${ }^{1}$ Department of Zoology, Faculty of Science, Damnhour University, El Behara, Egypt ${ }^{2}$ Department of Biology, College of Medicine, Dammam University, Saudi Arabia, KSA ${ }^{3}$ Department of Zoology, College of Science, King Saud University, Saudi Arabia, KSA ${ }^{4}$ Department of Zoology, Faculty of Science, Alexandria University, Alexandria, Egypt

(Corresponding author email: *Dr_eman_hashem@yahoo.com)
\end{abstract}

\begin{abstract}
The shape and microscopic structure of the foot of the oyster were described by light and electron microscopy. The foot is wedge-shaped with vertical furrows on the surface; it is composed of an epithelial layer, a connective tissue layer and a muscular layer. The epithelial layer was composed mostly of ciliated columnar epithelia and secretory cells. The cilia and microvilli were observed on the free surface of epithelial cells. The muscle fibers were composed of thin and thick microfilaments. Thick and thin filaments in muscle cells were reported in the foot as well as lateral projections of the cytoplasm contained granules. The outer surface of the periostracum of the shell is reported to be microridge and microfringe were present as well. The simplicity of periostracum of the shell layers was observed as thin simple layer whereas the prismatic layer was the opposite. Wedge-shaped and elongated prisms were reported near the outer surface. Fine lamellae were representing the nacreous layer and were divided by laminar inclusion. Micro-fringes were considered to be helping the direction of bivalve
\end{abstract}

Keywords: Bivalve, Pinctada radiata, periostracum, prismatic layer, nacreous layer, foot.

\section{Introduction}

The shell of bivalve; Unionidae was considered to have three layers by Nadim et al., (2008); periostracum, prismatic layer and the nacreous layer, whereas Cuif et al., (2008) reported that nacreous substances is formed after the deposition of the periostracum like layer onto the nucleous. Carter (1990) described the organization patterns of structures of periostracum of different groups by using scanning electron microscope. Nadim et al. (2008) observed and reported seven types of morphology in fifty bivalve families. In most in faunal bivalves, the foot is large and wedge shaped, being adapted for burrowing in soft substrate. It is also laterally flattened, highly muscular and extends nearly the entire ventral surface of the visceral mass (Eble, 2001).

The study of the extracellular granules had attracted most of scientists for their possibility of accumulating pollutants (Bryne, 2000). Sokolova, (2004) and Alfarraj et al., (2011) reported that the excess metal ions may be toxic to bivalve. Naser (2012) found out that oyster can highly accumulate Cd more than that was found in the surrounding habitat. Describing and comparing the forms of outer and inner shell structure of Pinctada radiata was the first goal of the present study, to complement biological studies conducted on Pinctada radiata (Leach, 1814) from two different sites of pollution in the Mediterranean coast of Alexandria, (Eastern harbor, and El Asafra), Egypt.

\section{Materials and Methods}

Twenty of Pinctada radiata of different lengths were collected from two locations; (Eastern harbor and El Asafra) during January 2011 and being put in plastic bags then moved to the laboratory.

\section{TEM of foot:}

Preparation of foot specimen for electron microscopy was performed according to be fixed in $2.5 \%$ glutaraldehyde solution $(\mathrm{pH} 7.2$, buffered $0.1 \mathrm{M}$ phosphate buffer) for $2-4 \mathrm{hrs}$ at $4^{\circ} \mathrm{C}$ and rinsed in 0.1 $\mathrm{M}$ phosphate buffer and then post fixed in $1 \%$ osmium tetroxide (OsO4) solution for $2 \mathrm{hrs}$ at $4^{\circ} \mathrm{C}$. After fixation, the specimens were washed with $0.1 \mathrm{M}$ phosphate buffer 4 times for $2 \mathrm{hrs}$ and dehydrated with ascending grades of ethanol. Specimens were cut at ultrathin 
sections (70 $\mathrm{nm}$ in thickness) and placed on copper grids (200 mesh) in order to double-stain with uranylacetate and lead citrate. Specimens were examined using a TEM (JEM-1200EXII, JEOL, Japan), Faculty of Science, Alexandria University.

\section{Histological study of the foot:}

Semithin sections of the foot $(0.5-1.0 \mu \mathrm{m})$ were cut using LK Bill ultra-microtome. In order to stain the resin embedded sections, they were rinsed for 1 - 2 minutes in about $1 \%$ toluidine blue solution in $1 \%$ borax. They were then washed in tap water, dried on hot plate (60C) and mounted in Canada balsam. Toluidine blue-stained sections were examined and photographed using Diallux 20EB Leitz research microscope provided with Canon camera. Ultrathin sections were cut from the resin blocks at a thickness of $10 \mathrm{~nm}$ using glass or diamond knives.

\section{SEM of the shell:}

For the shell scanning electron microscopy was performed according to be investigated under a scanning electron microscope (SEM) using polished thin sections and fragments of surface samples as well as under electron backscattered diffraction (EBSD). The following macroscopic reference frame: all sample wafers were obtained from a longitudinal cut through the shell that ranged from the hinge to the commissure of the valve. The sample wafers were 200 micrometer thick and placed 90 degrees to the plane of cut onto a glass holder. Samples were subsequently prepared on both sides of the shell as highly polished, $150 \mu \mathrm{m}$ thick sections. The surface of the thin sections was subsequently etched for $45 \mathrm{~s}$ with a suspension of alumina nanoparticles. The samples were then cleaned, dried, and coated with the thinnest possible conducting carbon coating (SEM: 4-6 $\mu \mathrm{m}$ and EBSD:15 $\mu \mathrm{m}$. Scanning electron micrographs and EBSD patterns were obtained on a LEO Gemini 1530 SEM.

\section{Results}

The histological analysis of the foot of Pinctada radiata revealed that it is composed of an epithelial layer, connective tissue layer and a muscular layer. The epithelial layer has definitive boundary. The epithelial layer of the foot was mostly composed of ciliated columnar epithelia and mucous cells. Epithelial cells forming the apical region of the fold were long columnar, while cells of the interfold were mostly short columnar. Epithelial cells forming the apical region of the fold were long columnar, while cells of the interfold were mostly short columnar (fig.9 A,B).

TEM observation (fig.10), revealed that ciliated columnar epithelial cells in apical region of the fold have well-developed cilia and microvilli on the free surface. The nucleus was oval shaped and located in the middle or basal portion of the cell. Epithelial cells in lateral and basal regions of the fold have well-developed cilia and microvilli on the free surface. These cells have irregular oval shaped nucleus in the basal cytoplasm and heterochromatins with high electron density are distributed near the nuclear membrane. The cytoplasm was filled with secretory granules of low electron density. Muscle fibers and some collagen fibers were observed in the muscular layer. The muscle fibers were composed of thin and thick microfilaments.

The shells of Pinctada radiata is found to be consisting of priostracum, prismatic and nacreous layer (figs.; 1-8), the foot of Pinctada radiata (figs.; 9-11) showed thick and thin filament muscle fiber, dense bodies were present as well. Cytoplasmic projections contained granular material. Periostracum-outer layer of the shell: The periostracum surface presents folds, corrugations, micro ridges are described (figs. 5-8): The periostracum is considered smooth and the folds are closer in the posterior. Raws of radial sequences of short convex arches arranged (3-7). Periostracal projections formed raws of fringes covering the shell outer surface. Shells of oyster collected from (E.H.) (figs. 7, 8); were dark brown in color than those collected from El Asafra. In the larger individuals collected from both locations; folds, corrugations, and projections were observed. In the internal shell structures, prismatic and nacreous layers were seen. The lines which separate the calcite and aragonitic areas can be seen from the internal side of the shell.

In the present study; the collected oyster shells from the E.H. (figs.3, 4) have much fragile in the prismatic layer. Malformed microstructure of aragonite layer was noticed in the shells collected from E. H. (figs. 3, 4, 7 and 8). The aragonite crystals showed irregular arrangement.

For the shell of oysters which were collected from El Asafra, the scanning electron shell micrograph showed the presence of $\mathrm{Cd}, \mathrm{Pb}$ and $\mathrm{Ca}$ and their percentages in the shell was reported as; $\mathrm{Ca} ; 98.4 \%, \mathrm{Cd} ; 0.1 \%$ and $\mathrm{Pb} ; 1.5 \%$ ;respectively, whereas, that of the Eastern Harbor was $\mathrm{Ca} ; 97.8 \%$, Cd;0.0\% andPb;2.2\%; respectively. The present results showed that the shell that was collected from El Asafra has more calcium than that of the Eastern harbor and that only $\mathrm{Cd}$ and $\mathrm{Pb}$ were recorded (histograms 1\&2).

\section{Discussion}

Histological analysis of bivalve foot have revealed that it is composed of an epithelial layer, which is simple and composed of columnar epithelial cells and secretory cells, a connective tissue layer, which is relatively thin, and a muscular layer, which is composed mainly of collagen fibers and smooth muscle fibers (Eble, 2001). Analysis of $M$. mercenaria foot revealed that it is covered with simple columnar epithelia that are ciliated near the tip of the anterior extremity (Eble, 2001). This general structure was found here, where the foot of Pinctada radiata was shown to possess an epithelial layer, connective tissue layer, and a muscular layer. Our analysis also revealed that the foot epithelial layer of Pinctada radiata was similar to $M$. mercenaria (Eble, 2001). Ciliated columnar epithelium in bivalves has also been reported in Solemyareidi (Gustafson and Reid, 1988). The characteristics of mucous secreted by the gland cells by the foot have been reported to be speciesspecific (Davies and Hawkins, 1998). Foot mucous cells of $M$. mercenaria were reported to contain acid glycos-aminoglycans rich in sulfate and carboxylate groups (Eble, 2001). 


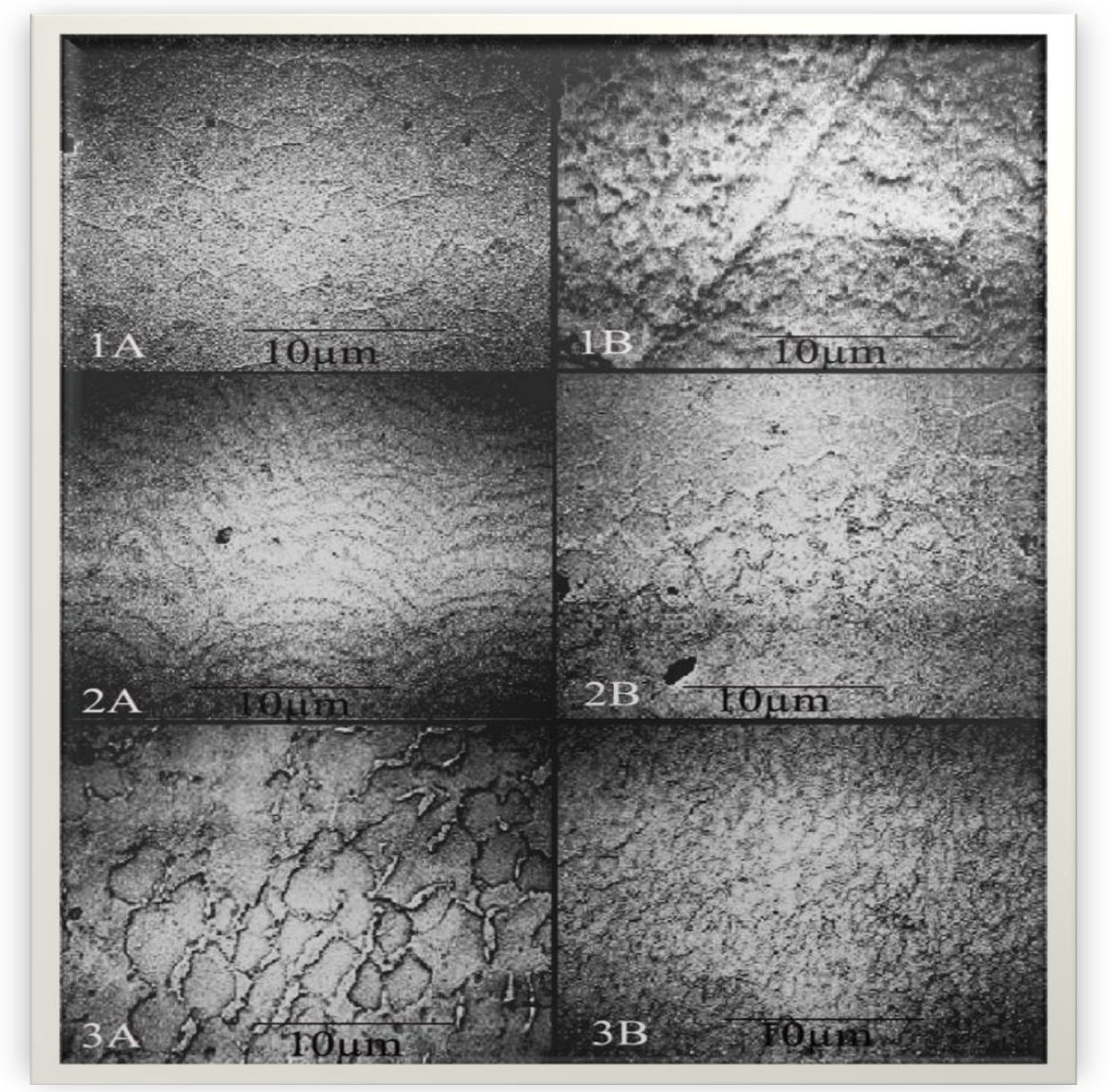

Fig. 1. (A): .SEM micrograph of the inner shell of Pinctada radiate from El Asafra showing, aragonite and the outer prismatic layer. The inner periostracum foliates and becomes mineralized, giving rise to the inner nacreous shell. (B): Higher magnification of SEM micrograph of the inner shell of Pinctada radiata, El Asafra showing, some free nacreous units, which form within the extrapallial fluid, later adhere to the nacreous layer.

Fig. 2:(A): SEM micrograph of the inner shell of Pinctada radiata, from El Asafra showing the outer prismatic layer of the shell.(B): Higher magnification of SEM. micrograph of the inner shell of Pinctada radiate showing normal arrangement of the architecture of the prismatic layer of the shell.

Fig. 3:(A): SEM micrograph of the inner shell of Pinctada radiate from Eastern Harbor, showing aragonite layer.(B): Higher magnification of SEM. micrograph of the inner shell of Pinctada radiate showing the outer prismatic layer with abnormal arrangement of the prismatic layer. The shell having much fragile in the prismatic layer. Malformed microstructure of aragonite layer. 


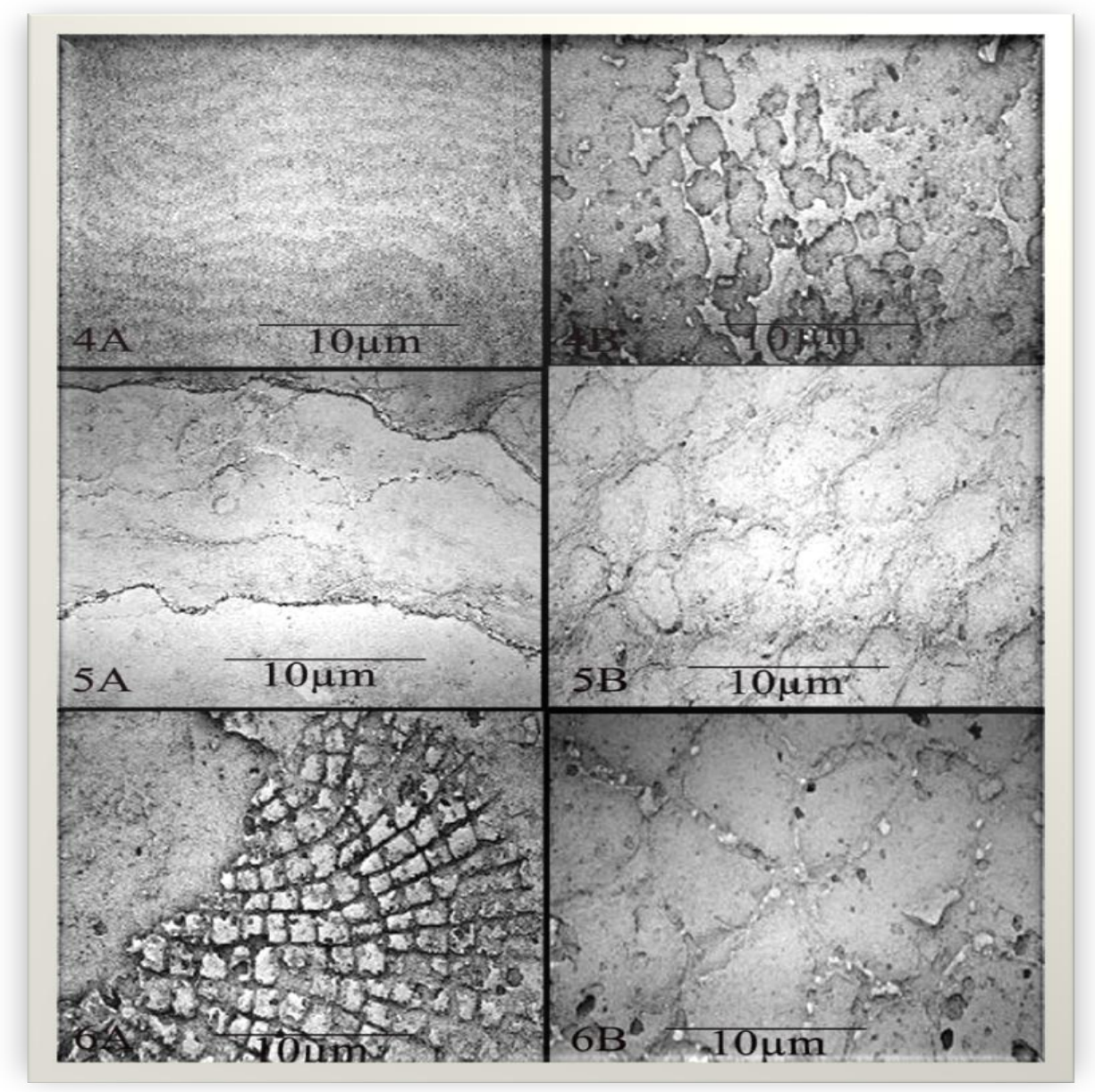

Fig. 4:(A): SEM micrograph of the inner shell of Pinctada radiate from Eastern Harbor, showing he transition between the prismatic and nacreous layers in Pinctada radiata. The internal fibrous structure of prisms is also evident with growth, fibres align progressively with the long axis of the prism. Some prisms that disappear by competition are still visible in the outer part. (B): Higher magnification of SEM micrograph of the inner shell of Pinctada radiata.

Fig. 5:(A): SEM micrograph of the outer shell of Pinctada radiata, El Asafra region, showing a thicker periostracum layer. When this periostracum is extruded, the inner surface of the outer mantle fold secretes a third layer (the inner periostracum) below the middle periostracum. The inner periostracum later separates from the middle periostracum and develops folds, which disappear before the whole periostracum reflects at the shell margin.(B): SEM micrograph of the higher magnification of outer shell of Pinctada radiata from El Asafra.

Fig. 6: (A): SEM micrograph of the outer shell of Pinctada radiata, El Asafra region, showing the periostracum which is considered smooth and the folds are closer in the posterior. Raws of radial sequences of short convex arches arranged (37) (B): SEM. micrograph of the higher magnification outer shell of Pinctad aradiata, El Asafra. 


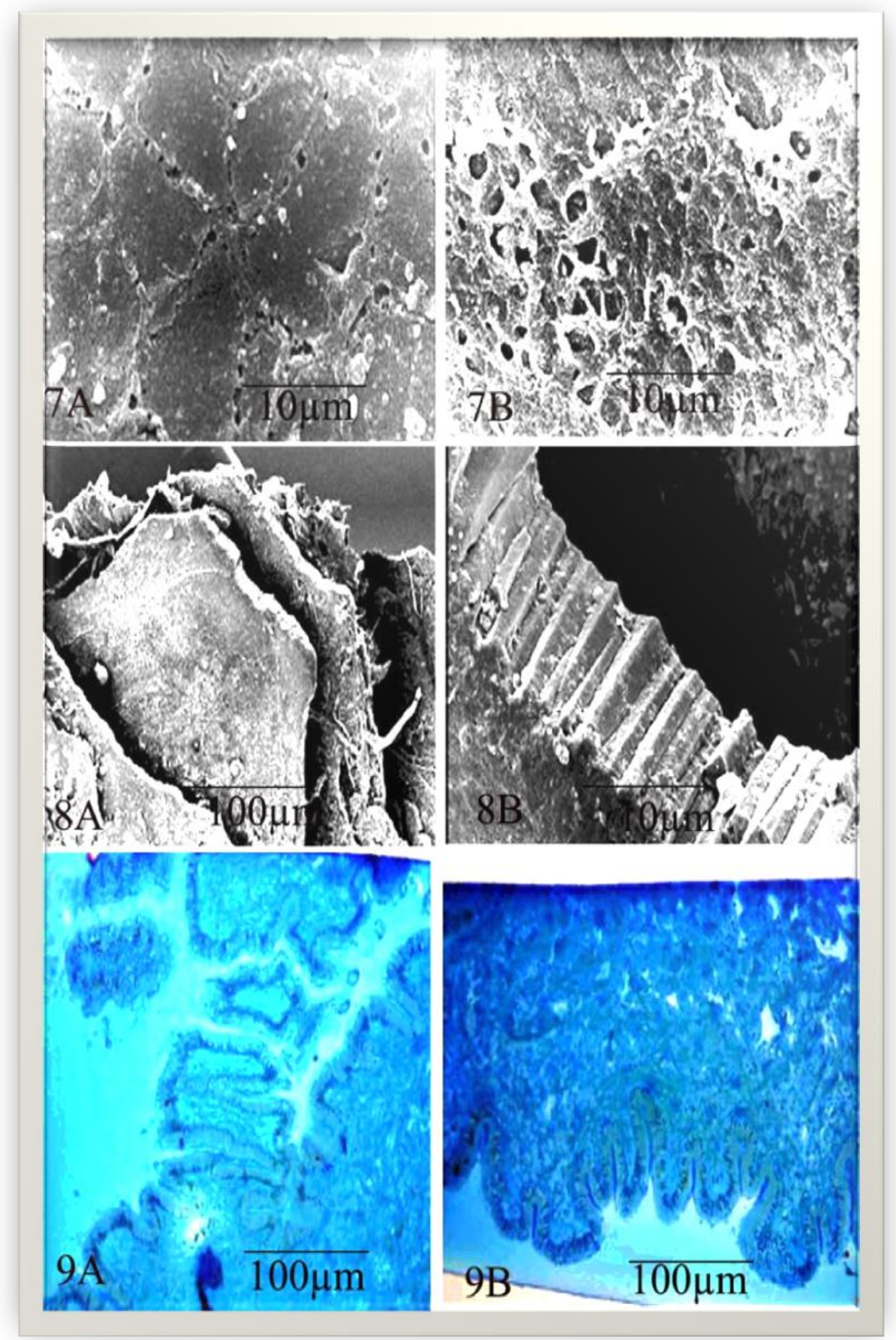

Fig. 7: (A): SEM micrograph of the outer shell of Pinctada radiata, Eastern Harbor region, showing periostracal projections forming raws of fringes covering the shell outer surface. (B): Higher magnification of SEM micrograph of the outer shell of Pinctada radiata, Eastern Harbor.

Fig. 8: (A): SEM micrograph of the outer shell of Pinctada radiata, Eastern Harbor. (B): SEM micrograph of the outer shell of Pinctada radiata, higher magnification.

Fig. 9: (A): Photomicrograph (Semithin) of a foot of Pinctada radiata, Eastern Harbor region. (B): Photomicrograph (Semithin) of a foot of Pinctada radiata, El Asafra region, showing the ciliated columnar epithelium layer. 


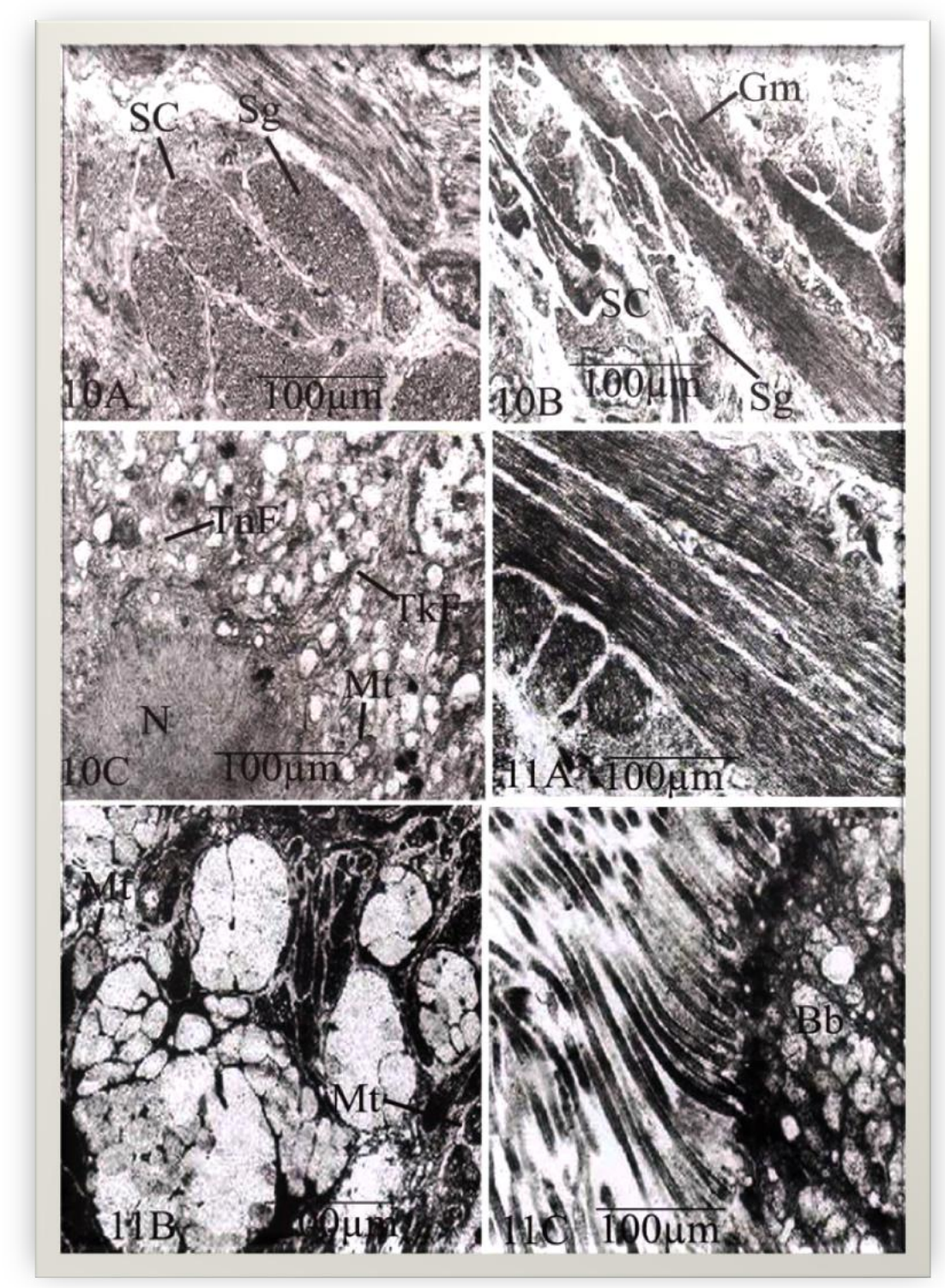

Fig. 10 (a, b, c): Photomicrograph of (TEM) of oyster collected from El Asafra region showing secretory cell (Sc) and secretory granules (Sg). Thin (Th.F.) thick filaments (Tk.f.) were seen.

Fig. 11 (a, b, c): Photomicrograph of (TEM) of oyster collected from Eastern Harbor region showing secretory cell (Sc.) and secretory granules (Sg.). Thin (Th.F.) thick filaments (Tk.f.), ciliated columnar epithelial cells 


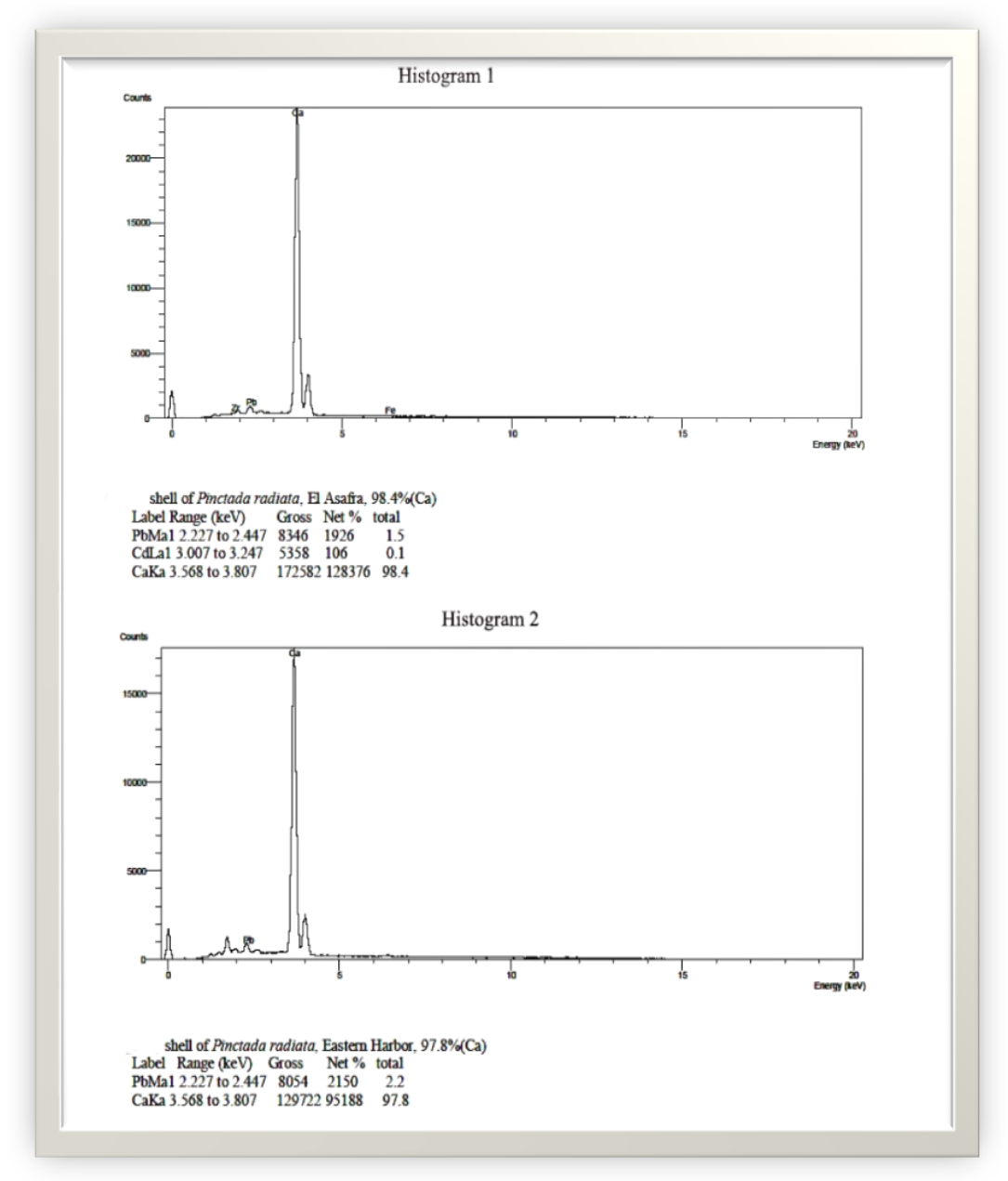

Invertebrate smooth muscle differs from that of vertebrates, margaritifera (Caseiro, 1993). According to Saleuddin and principally in the higher proportion and larger diameter of Petit (1983) the "free periostracum, could form complex thick myofilaments (Paniagua et al., 1996). Muscle fibers loops in the extrapallial space during preiostracum in the translucent part of the adductor of Crassostera formation. The parasite like bodies (PLBs) were first angulata contained thick and thinner filaments (Hanson considered by grafters as a parasite, suspected to induce and Lowy,1961). flaws in the nacreous layer of the pearl (Marin and Carter (1990) reported that; the prismatic layer is classified as regular simple prismatic layer. The present study agrees with that reported by Carter in the most collected shells from El Asafra. In the present study pentagonal and hexagonal prisms are reported in oyster shells collected from both locations. In the present study, the separation of calcific and aragonite areas are visible in the inner part of the shell and that agrees with the results of Cuif et al. (2008) who reported a clear visibility of the line that separates aragonite from calcite in bivalve inner shell. The abnormal organo-mineral associations observed in the basal pearl layer can be interpreted as a consequence of the uncontrolled mineralization process in early stages of pearl sac formation (Cuif et al., 2008).

In the bivalves, the aragonite crystals of the nacreous layer of the shell are underplayed by an organic matrix elaborated by epithelial cells of different regions of the mantle during the bio mineralization cycle (Wada, 1987). Similar organic structure is also observed in the nacreous layer formed on the surface of the pearl in Pinctada Duaphin, 1992), but their causes remain unknown at present (Cuif and Dauphin, 1996). The production of nacreous crystals could be stopped by stress caused by grafting, and a purely organic layer showed be deposited on the nucleus. The epithelium which supplies the crystal deposit may also consist of areas of cells involved in periostracum production (Naser, 2010 \& 2012).

The majority of granules occurred in clusters of among lateral processes of muscle cells rather than enmeshed in collagen fibers as in the Unionid anodonta. The vesicular cells in H.depressa and V. ambiguous appear similar to the leydig cells described in many molluscs (Berthelin et al., 2000). These cells store large amounts of glycogen and act as a nutrient reserve (Pipe, 1987). Some intracellular granules that could be cut relatively easily in thin sections and that stained blue with toluidine blue in the thick sections are probably not calcium phosphate, but may have a sulfur- based composition (Vesk and Byrne, 1999).

Phosphate-rich granules tent to be associated with socalled "hard acid" metals, such as $\mathrm{Ca}$, whereas granules rich 
in sulfur (such as are common in oyster haemocytes) exhibit a different chemistry and tent to be associated with "soft acid" or $\mathrm{Cu}$ (Coville and Lim, 2003), considered that the granules in Anodonta cygnea and Hyridella depressa are formed within the amorphous vesicles of haemocytes, which they termed" concretion- forming cells"or (CFCs).In mussels; the outer epithelial cells of the mantle appear to function mainly to store glycogen. There was little cellular machinery to suggest active secretion of shell material (Coville and Lim, 2003; Hedge et al. 2009).

The difference in the cellular structure may reflect phylogenetic differences or functional differences (Coville and Lim, 2003). Bryne (2000) speculated that the distribution of granules in the interstitial tissues of mussels may be a useful character in phylogenetic analyses.

Alexandria rocky shores constitute a major part of the coastal marine ecosystem where many species of fauna are associated (Abd El-Naby, 1999). Alexandria coast was recognized as a highly contaminated site with trace metals due to heavy industrial, agricultural and sewage disposals (El-Deeb and Aboul-Naga, 2002). Trace elements enter the marine environment from both natural and anthropogenic sources. The metal which is of great concern in fresh and brackish waters is $\mathrm{Pb}$ (Abdul Nabi et al., 2002).Coastal water can receive significant inputs of lead from industry and/or sewage of the water sheds and lead concentrations in them can reflect these inputs (Shakweer et al., 2006). Sources for Cd exposure are air and water and hazardous wastes (APHA, 1986).

The metal which is of great concern in fresh and brackish waters is Cd (Abdul Nabi et al., 2002). El-Sikaily et al. (2003) and Shakweer et al., (2006) revealed that the origin of trace elements in the water of the Egyptian Mediterranean is mainly the waste water discharge. Tomazelli et al. (2003) found that the degree of environmental contamination is only one among several factors that influence metal concentrations in animals. Bioavailability or specific sources may be responsible for higher concentrations in apparently less impacted environments. Bivalves are frequently used in marine eco toxicology for the purpose of assessing seawater quality because they are very sensitive to pollutants (Geffard et al., 2004).

The Egyptian Mediterranean coast has been influenced by untreated urban and industrial effluents that caused coastline degradation (NDA Egypt, 2003 and EEA, 2005), particularly in Alexandria coast due to the high population growth and rapid development (EEA, 2005). Gagné et al. (2002) reported that $\mathrm{Cd}$ accumulated significantly in mussels. Chemical compounds that are dumped in the environment reach shellfish harvesting waters where they are concentrated. Lead is leader member of the toxic metals in the marine environment (Madkour, 2005).Some molluscan species represent a valuable seafood source. High concentration of heavy metals in molluscan species give dangerous indicator to deteriorate the marine life and pose a health risk to human. Exposure to $\mathrm{Pb}$ generally resulted in reduced oyster growth (MacFarlane et al., 2005; Gifford et al., 2006).
The bioavailability of metals such as lead concentrations in soft tissues of oysters Pinctada imbricatais highly dependent on the speciation or physicochemical forms of themetals in seawater (MacFarlane et al., 2005).

\section{References}

Abd El Naby, FA (1999). Composition and distribution of some bottom fauna associationalongtheAlexandria Coast, Mediterranean Sea. M.Sc. Thesis, Alexandria University.

Abdul Nabi, BM (2002). Xenobiotics and the susceptibility of Oreochromis niloticus (Linnaeus, 1757) from lake Maryut to environmental interactions and Hepatic Bio transformations. M.Sc. Thesis. Faculty of Sci., Univ. of Alex.

Al Farraj S, El-Gendy AH, Alyahya H, El-Hedeny M (2011). Heavy metals accumulation in the mantle of the common cuttlefish Sepia pharaonis from Arabian Gulf. Aust. J. Basic. Appl. Sci. 5(6):897-905.

APHA (American Public Health Association)(1986). Standard Methods of Water and WasteWater,16th Ed., APHA, Washington,: 96-98

Berthelin, C.; Kellner, K.; and Mathieu, M. (2000): Histological characterization and glucose incorporation into glycogen of the pacific Oyster Crassostrea gigas storage cells. Marine Biotechnology.2: 136-145.

Byrne M.(2000). Calcium concentrations in the interstitial tissues of the Australian Freshwater mussel Hyridella depressa (Hyriidae). In "The Evolutionary Biology of the Bivalvia".(Eds. EMHarper, JD Taylor and JA Crame) pp:29-43.

Carter JG (1990). Skeletal biomineralization: patterns, processes and evolutionaryTrends.I.NewYork, Van Nostrand Reinhold, 2:832.

Caserio J (1993). La nacre noire de Polynesie, Biomineralization, parameters et processus decroissance, effects chromatiques dans la coquille et la perle de Pinctada margaritifera. These, doctorat Univ. Claude Bernard-Lyon.

Colville AE and Lim RP (2003). Microscopic structure of the mantle and palps in the Fresh water mussels Velesunio ambiguous and Hyridella depressa (Bivalvia: Hyriidae).Molluscan Research, 23: 1-20.

Cuif JP and Dauphin Y (1996). Occurrence of mineralization disturbances in nacreous layers of cultivated pearls produced by Pinctada margaritifera from French Polynesia, comparison with reported shell alterations, Aquat. Living Resorir (9), 187-193.

Cuif J-P and Ball AD and Dauphin Y and Farro B and Nouet $J$ and Perez-HuertaA, Salome $M$ and Williams CT.(2008). Structural, mineralogical, and biochemical diversity in the lower part of the pearl layer of cultivated seawater pearls from Polynesia. Microscopy and Microanalysis,14(5): 405-417.

Davies MS and Hawkins J .(1998). Mucus from Marine Mollusks.Advance in Marine Biology, 34:.1-71.

Eble AF. (2001). Anatomy and Histology of Mercenaria mercenaria, In: J. N. Kraeuter and M. 
Castagna, Eds., Biology of the Hard Clam, Elsevier, New York, pp.117-220.

EEA (European Environment Agency)(2005). Priority issues in the Mediterranean Environment EEA Report No 5/2005.

El Deeb MK and Aboul-Naga W (2002). Trace metals:Fe, Zn, Mn, $\mathrm{Ni}$ and $\mathrm{Cr}$ in Macroalgae fromAlexandria coast. Bull. Fac.Sci. Alex. Univ.. 42(1,2): 51-60.

El Sikaily A, Khaled A, El-Nemr A (2003). Heavy metals monitoring using bivalves from Mediterranean sea and red sea. Environmental Monitoring and Assessment 98:1-18.

Gagné F, Blaise C, Aoyama I, Luo R, Gagnon C, Couillard Y, Campbell P and Slazar M(2002).Biomarker study of municipal effluent dispersion plumme in two species of freshwater mussels. Environ. Toxicol., 17: 149159.

Geffard O,Budzinski $\mathrm{H}$ and His E (2004). The effects of elutriates from PAH and heavy Metal polluted sediments on Crassostrea gigas (Thunberg) embryogenesis larval growth and bio-accumulationby the Larvae of pollutants from sedimentary origin. Ecotoxicology.11(6): 403-16.

Gifford S, MacFarlane G R, O`Connor W and Dunstan RH (2006). Effect of the Pollutants; lead, zinc, hexadecane and octocosane on total and shell growth in the Akoya pearl oyster, Pinctada imbricata. Journal of Shellfish Research. 25: 159-165

Gustafson RG and Reid RGB (1988). Larval and Post-Larval Morphogenesis in the Gutless Protobranch Bivalve Solemyareidi (Cryptodonta: Solemyidae)," Marine Biology, 97(3): 373-387.

Hanson J. and Lowy L. (1961). The Structure of the Muscle Fibers in the Translucent Part of the Adductor of the Oyster Crassostrea angulata, Proceedings of the Royal Society B, 154(955): 173-196.

Hedge L, Knott A, Johnston E (2009). Dredging related metal bioaccumulation in oysters. Mar. Pollut. Bull. 58:832-840.

MacFarlane GR, Markich SJ, Linz K, Giffords Dustan RH, O'Conner W and Russell RA(2005). The A'Koya pearl Oyster shell as an archival monitor of lead exposure. Environmental Pollution. 143: 166-173.

Madkour HA (2005). Distribution and relationships of heavy metals in the Gaint clam (Tridacna maxima) and associated sediments from different sites in the Egyptian Red sea Coast. Egyptian Journal of Aquatic Res. 31(2): 4559.

Marin F and Dauphin Y (1992). Malformations de la couche nacre de l' huitreperliere (L.) de laPolynesie Francaise: rapport entre alterations microstructuraleset composition. Ann. Sci. Nat. Zool/Paris; 13:157-168.

NDA Egypt.( National Diagnostic Analysis) Egypt (2003). UNEP/MAP48.
Nadim F, Bagtzoglou AC, Iranmahboob J (2008). Costal management in the Persian Gulf region within the framework of the ROPME programme of action.Ocean. Coast. Manage.51:556-565.

Naser HA (2010). Testing taxonomic resolution levels for detecting environmental impacts using macrobenthic assemblages in tropical waters. Environ. Monit. Assess. 170:435-444.

Naser H (2012). Metal Concentrations in Marine Sediments Influenced by Anthropogenic activities in Bahrain, Arabian Gulf. In: Hong-Bo, Shao (Ed.), Metal Contaminations: Sources, Detection and Environmental Impacts. NOVA Science Publishers, Inc., New York, pp. 157-175.

Paniagua R, Royuela M, Garcia-Anchuelo RM and Fraile, B (1996). Ultrastructure of Invertebrate Muscle Cell Type. Histology and Histopathology, 11: 181-201.

Pipe RK(1987).Ultrastructural and cytochemical studies on interactions between nutrient Storage cells and gametogenesis in the mussel Mytilus edulis. Marine Biology.96: 519-528.

Saleuddin ASM and Petit HP (1983). The mode of formation and the structure of the periostracum, in: The Mollusca, Vol. 4, pp. 199-234.

Shakweer LM, Shiridah M, Fahmi M and Abd El Fatah (2006).Distribution and Concentrations of trace elements along the Mediterranean coastal water of Egypt. Egyptian Journal of Aquatic Research. 32.(2): 95-127.

Sokolova IM (2004). Cadmium effects on mitochondrial function are enhanced by elevated temperatures in a marine poikilotherm, Crassostrea virginica Gmelin (Bivalvia: Ostereidae). J. Experimental Biology, 207:2639-2648.

Tomazelli AC, Martinelli LA, Avelar WEP, de Camargo PB, Fostier AH, Ferraz ESB, Krug FJ and Junior DS (2003). Biomonitoring of $\mathrm{Pb}$ and $\mathrm{Cd}$ in two impacted watersheds in Southeast Brazil Using the Freshwater Mussel Mycetopodidae) as a biological Monitor. Brazilian archives of Biology and Technology. 46 (4): 673-684.

Vesk PA and Byrne M (1999). Metal levels in tissue granules of the freshwater bivalve Hyridella depressa (Unionida) for biomonitoring: The importance of cryopreparation. Science of the total Environment, 225:219-229.

Wada K (1987). Electron-microscopic observations of the shell structures of pearl oyster (Pinctada martensii).II. Observations of the aragonite crystals on the surface of nacreous layers, Bull. Nat. Pearl Res. Lab. (Jpn) 2:74-85 